Article

\title{
An Integrated Methodology of Subjective Investigation for a Sustainable Indoor Built Environment. The Case Study of a University Campus in Italy
}

\author{
Erminia Attaianese $^{1}\left(\mathbb{D}\right.$, Francesca Romana d'Ambrosio Alfano ${ }^{2}\left(\mathbb{D}\right.$, Boris Igor Palella $^{3, * \mathbb{C}}$, Daniela Pepe ${ }^{2}$ \\ and Roberto Vanacore ${ }^{4,+}$ \\ 1 Dipartimento di Architettura (DiARC), Università degli Studi di Napoli Federico II, Via Toledo 402, \\ 80135 Naples, Italy; erminia.attaianese@unina.it \\ 2 Dipartimento di Ingegneria Industriale (DIIn), Università degli Studi di Salerno, Via Giovanni Paolo II 132, \\ 84084 Fisciano, Italy; fdambrosio@unisa.it (F.R.d.A.); dpepe@unisa.it (D.P.) \\ 3 Dipartimento di Ingegneria Industriale (DII), Università degli Studi di Napoli Federico II, \\ Piazzale Vincenzo Tecchio 80, 80125 Naples, Italy \\ 4 Dipartimento di Ingegneria Civile (DICIV), Università degli Studi di Salerno, Via Giovanni Paolo II 132, \\ 84084 Fisciano, Italy \\ * Correspondence: palella@unina.it; Tel.: +39-081-768-2618 \\ + Deceased.
}

check for updates

Citation: Attaianese, E.; d'Ambrosio Alfano, F.R.; Palella, B.I.; Pepe, D.;

Vanacore, R. An Integrated

Methodology of Subjective

Investigation for a Sustainable Indoor Built Environment. The Case Study of a University Campus in Italy. Atmosphere 2021, 12, 1272. https:// doi.org/10.3390/atmos12101272

Academic Editor: Ashok Kumar

Received: 27 August 2021

Accepted: 26 September 2021

Published: 29 September 2021

Publisher's Note: MDPI stays neutral with regard to jurisdictional claims in published maps and institutional affiliations.

Copyright: (c) 2021 by the authors. Licensee MDPI, Basel, Switzerland. This article is an open access article distributed under the terms and conditions of the Creative Commons Attribution (CC BY) license (https:// creativecommons.org/licenses/by/ $4.0 /)$.
Abstract: Indoor built environments' design and management require a holistic approach inspired by ergonomic principles and sustainability criteria. This is especially in case of renovation of existing buildings where any kind of intervention requires the direct feedback of occupants. This work deals with two aspects of these issues, often studied separately: the quality of interior spaces, in terms of Indoor Environmental Quality (IEQ), and the quality of the architecture in terms of orientation and wayfinding. A methodology focused on the subjective evaluation of the IEQ giving relevance to users and their fruition needs is also proposed. Main findings from a specific subjective investigation carried out at the Fisciano Campus of the University of Salerno (Italy) demonstrate that the subjective approach is a valuable tool to make more sustainable intervention strategies. In this way, all multidisciplinary skills can be synergically involved in improving the livability of a complex reality as University Campuses are.

Keywords: indoor environmental quality; wayfinding; thermal comfort; indoor air quality; subjective surveys; university campus; sustainability

\section{Introduction \\ 1.1. Background}

The scientific and industrial revolutions and the subsequent technological progress resulted in the breaking of the balance between man and nature up to climatic changes, whose effects are starting to be irreversible [1]. To restore that equilibrium, specific solutions aimed at saving energy in buildings are necessary. Hence, the stringent need to build NZEB (Nearly Zero Energy Building) [2-7], whose design requires a holistic approach based upon the principles of sustainability. Consequently, building design should be compliant with NZEB requirements in terms of energy-saving, indoor environmental quality (IEQ), fire safety, and risks related to intense seismic activity [8] with water savings, sustainable mobility, the presence of greenery (which also inspire the biophilic design movement in architecture $[9,10]$ ), and additional conditions including the well-being of people $[8,11,12]$. Even though many of these criteria are adopted by the common multicriteria decision-making techniques used in the field of building sustainability assessment [13], the human factor's main issues are still lacking in the main international building certification protocols [14]. 
The relationship between the quality of the architectural space and IEQ is a topic that is acquiring growing importance in the disciplinary debate. This implies an anthropocentric approach to the indoor built environment design in compliance with the basic principles of ergonomics/human factors [15-17]. This is especially because the indoor environment has a potential impact on occupants' health and productivity, affecting their physical and psychological conditions $[18,19]$.

These issues are of great importance on campuses, which are small towns inhabited by communities of people of different ages, habits, and cultures who share classrooms, offices, and common spaces for several hours a day. Campuses are complex organisms characterized by many activities available to people living and working there (studying, playing sports, accommodations, entertainment, artistic activities, etc.), great autonomy despite their strong relationship with the surrounding territory and, finally, a significant environmental impact due to their energy consumption and considerable waste and emissions [20].

This is why they should represent a virtuous example of sustainability, in which the objective is extended from the building to a wider context, which can be assimilated to the urban one.

Therefore, to make university campuses efficient, a series of actions aimed at facilitating and optimizing the activities of users are necessary to improve socialization by creating pleasant and comfortable environments for the community that lives in these spaces $[21,22]$.

This approach is the result of an extensive renewal process that is affecting the field of the educational building. In fact, in recent years, the concept of learning environment evolved as a physical and/or virtual place, but also as a mental and cultural, organizational, and emotional/affective space, in which the teaching/learning process takes place. This conception of educational activity is progressively influencing the organization of the school spaces, with some innovative achievements both in Italy and abroad [23].

\subsection{Aim of the Paper}

This paper aims to promote a holistic approach to building sustainability by also considering functional, technical, physiological, and psychological features in which people are considered in their totality including physical, emotional, and perceptive issues. Consistently, the indoor environmental quality, shape and layout of the buildings, use of color clear distribution organization of spaces, ease of orientation, and adequate visual contact with the outside contribute to defining more adequate conditions of well-being for humans. Unfortunately, the combination of IEQ and functional issues of the built environment is not considered with the risks of unbalanced solutions in cases of both new and existing buildings. Therefore, most literature about university campuses is focused on the evaluation of only IEQ (e.g., objective, subjective, and integrated investigations) and related impact on work and learning performances [20,24-26].

Based on the above, this paper discusses how to improve the quality of building design by integrating IEQ and functional aspects of interiors while also considering orientation and wayfinding. As the first application of this methodology, which includes IEQ and some of the functional issues above discussed, the Campus of Fisciano of the University of Salerno (Italy) was considered. In this way, starting from users' needs identified through specific questionnaires, it is shown how an integrated approach can provide designers with an effective tool for qualifying and improving existing building complexes consistently with sustainability and human factors.

\section{Methodological Fundamentals}

\subsection{The Characteristics of Built Environment}

The built environment design needs to consider some basic characteristics including [27]:

- Safety: prevention of damage and risks deriving from natural and accidental factors to safeguard the health conditions and the safety of users [28,29]; 
- Well-being: adequacy of the building system to life, health, and the performance of user activities [27,30];

- Usability: appropriate use by users for the performance of their activities in terms of dimensional, distributive suitability, space habitability, accessibility as claimed the EN 17210 [31], and adaptability consistent with DfA (Design for All) principles [18];

- Aspect: the set of conditions relating to the perceptual fruition of the building system and the ability to express a recognizable identity [27,32];

- Management: economic feasibility, maintainability, and durability [20,27,33];

- Integrability: the set of conditions related to the attitude of the units and the elements of the building system to be functionally connected [24];

- Environmental sustainability: the ability of buildings to fit into the environment with a limited impact [20,34-37].

Not all characteristics refer to objective indices or indicators based on the measurement of physical quantities. For example, aspect and usability require subjective indicators, generally based upon questionnaires administered to users [37]. Therefore, a questionnaire is a tool for the evaluation of subjective parameters that contributes to giving information on the perceived built environment quality.

\subsection{Relationship between Built Environment and Human Factors}

The relationship between users and the built environment is affected by two main aspects:

a. Spatial factors, which include the conformation of places, way of orientation, and colors. They help users to orient themselves, understand where they are, and immediately perceive the connections between the different environments of a building. This issue responds to a precise and profound psychological need, and it has a significant influence on the sense of well-being perceived by users [38]. To promote the readability and the accessibility of spaces, especially to people with disabilities, the wayfinding theory according to Weisman [39] should be used. That means creating a place where features and finishing of built environment support the different walking users consistently with comfort conditions, safety, and pleasantness. From the architectural design point of view, Weisman identified four categories of environmental variables affecting the performance of wayfinding: (i) the visual access to information; (ii) the degree of architectural differentiation; (iii) the use of signage; (iv) the configuration of the planimetry. According to Weisman's ideas, the main goal of designers should be to create distinguishable environments, making "finding the way" through a simple environmental layout easier $[40,41]$. A significant intervention concerned the Jussieu University campus in Paris with the construction of the 16M-Atrium building. This is a manifesto of vitality, functionality, and modernity in which the color emphasizes the rhythms of the activities that are hosted within it and becomes an element of orientation and identification of spaces. Colorimetry is so effective that the signage is practically useless. From any point in the atrium, at any altitude, the colors allow to identify, unequivocally, the direction where you are headed [42].

b. Indoor Environmental Quality (IEQ) means thermal comfort, indoor air quality, visual comfort, and acoustic comfort [42-48]. IEQ affects physical and psychological health of building occupants and energy saving. A poor IEQ promotes increasing symptoms of SBS (Sick Building Syndrome), acute respiratory illnesses [49,50], allergies and asthma, sick leaves, and a significant reduction in people's performance [51]. Therefore, a poor IEQ could result in economic and social costs higher than those related to the correct design of buildings envelope and HVAC (Heating, Ventilation, and Air Conditioning) systems. The IEQ is included in the sustainability protocols and carried forward in Europe by the European Directive 844/2018 [8] and related standards [52,53]. Particularly, the directive prescribes that the information of indoor environment should be included in the energy certificate to estimate the total performance of a building. 


\subsection{An Integrated Methodology for Improving Existing Campuses}

Designing buildings conceived for optimizing the relationship among the built environment, users' needs, and saving energy is not so difficult, especially if the commissioning is planned [54,55]. To the contrary, the adaptation of the principles as above to existing building complexes as campuses can be a critical issue. To this aim, it is necessary a multidisciplinary team possibly made by architects, engineers, experts in building physics, HVAC systems, ergonomics, property and commitment, and final users. The team should operate at two levels: (i) by carrying out an extensive subjective investigation aimed at recording the feedback of users by highlighting the criticalities of spaces and the involved systems; (ii) by carrying out objective measurements of energy and IEQ parameters. Since each campus is a reality unto itself, placed in a specific context, it is hard to define general rules but all aims should be clear and shared.

\section{The Case Study: The Campus of the University of Salerno in Fisciano}

\subsection{General Data}

The case study concerns the presentation and discussion of a questionnaire submitted to the engineering students of the Campus of the University of Salerno in Fisciano.

The Campus of Fisciano, conceived as a real urban structure like other Italian Campuses (e.g., Cosenza, Chieti, and Parma), is one of the best known autonomous Italian university settlements, with formal and functional characteristics referable to the AngloAmerican model. Designed in 1974, the campus is a flexible building system, open and able to dialogue with the surrounding area.

The functional organizational model is defined by two types of elements, listed below respectively as "main building" and "secondary building" (Figure 1).

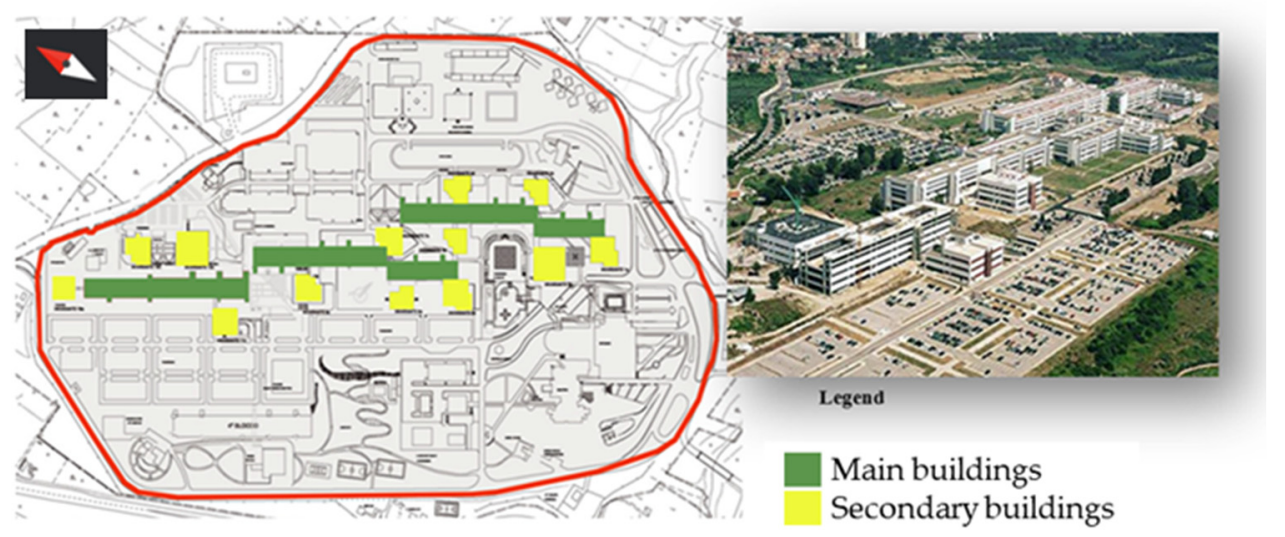

Figure 1. General Plane of Campus of Fisciano with identification of main buildings and secondary buildings.

These geometrically simple elements have high internal flexibility and contain modules characterized by repeatability and polydirectional growth. In particular, the main buildings can contain different aggregations of activities that can be adapted to the needs of users. The secondary buildings group large spaces for unique functions that do not change over time. Finally, there are connecting elements that are flow exchangers in which the covered paths that lead to the secondary buildings are grafted [37].

The main functional organizational model is matched by variations introduced by the representative architectures (office of the Rectorate), the equipment (libraries, hall, theatre, swimming pool, canteen, sports fields), some service buildings (banking and post office, multispecialist center for health care, police office, corporate nursery, and parking areas), and by residence for students and visitors. The campus buildings exhibit a reinforced concrete bearing structure and external walls in prefabricated concrete panels distinguished by the regular succession of ribbon windows. Facades are monotonous and uniform, while 
the planimetric layout is complex and articulated and appears like a sequence of open spaces and courts of various shapes and sizes.

The modular sequence characterizing the architectural composition of the campus does not facilitate the identification of the places to the users, resulting in a poor orientation both outside and inside the buildings. This is why an extensive redevelopment program aiming at improving the usability of spaces available to students, teachers, and all the users of the campus called "Costruendo Unisa" (Constructing Unisa) is affecting the university settlement for some years.

The colors of buildings were changed for facilitating the wayfinding and some panels were arranged in main and secondary buildings to facilitate the wayfinding, as shown in Figure 2.

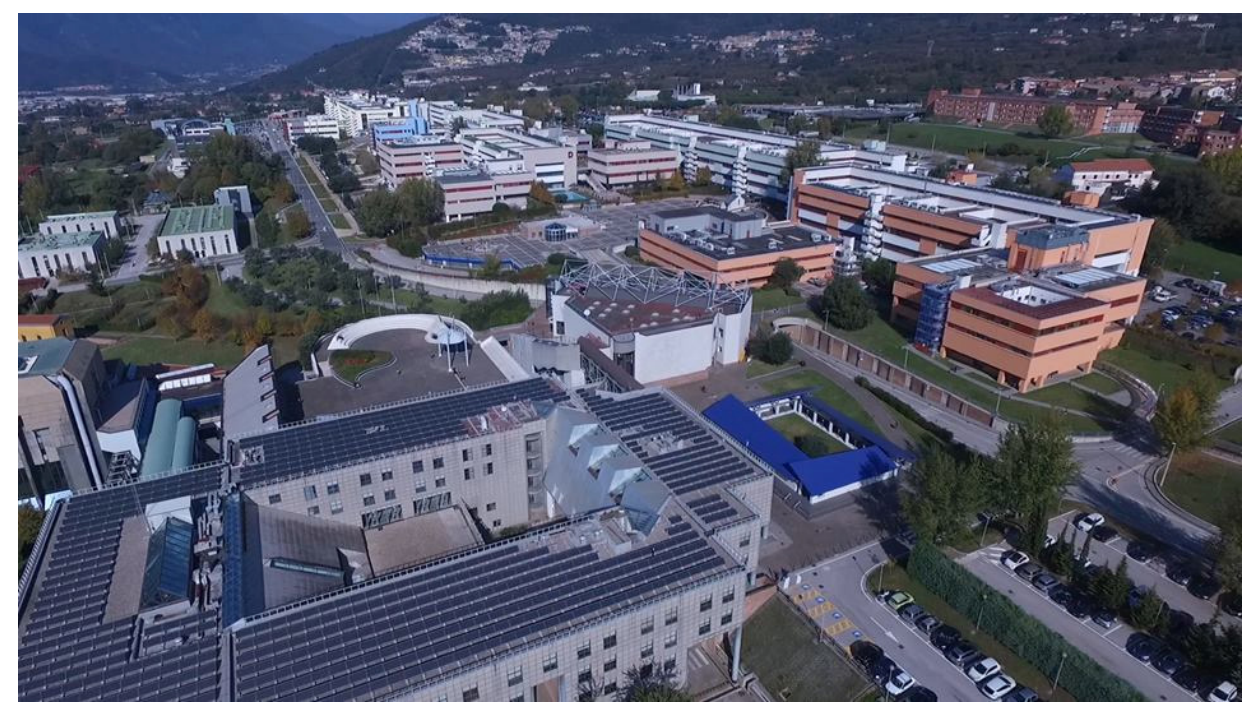

Figure 2. Campus of Fisciano today.

The classrooms are provided with the same finishing elements and furniture: white laminate walls, floors covered in PVC, desks and seats in metal and wood (formaldehydefree), and metal cabinets. The windows consist of double glazing and aluminum frame with external shading devices. Only the classrooms Candia and Easy PC are not equipped with shading devices. The window opening is allowed by sliding doors.

Heating and cooling systems operate in the period specified by Italian regulations. Furthermore, all classrooms are equipped with a Mechanical Controlled Ventilation System (MCV) with primary air entered from ceiling and recirculation. The air change rate values meet the recommendations of the Italian Standard UNI 10339 [56]. Terminal units of the HVAC systems consist of wall-mounted fan coils. The lighting system is equipped with LED lights installed in the false ceiling.

Other information about investigated classroom is summarized in Table 1.

\subsection{Subjective Integrated Investigation}

The integrated methodology here discussed is based upon a subjective assessment of IEQ and wayfinding of the campus. To this purpose, an existing and validated questionnaire focused on thermal comfort and designed by a team of engineers, psychologists, and doctors [57-60] was adapted for IEQ according to the recent ISO Standard 10551 [61]. To account for the quality in use of spaces, a specific section of the questionnaire was also designed (see Appendix A). 
Table 1. Main parameters characterizing investigated classrooms.

\begin{tabular}{|c|c|c|c|c|c|}
\hline Classroom & Floor Area $\left(\mathrm{m}^{2}\right)$ & Number of People & $\begin{array}{l}\text { Usable Surface } \\
\text { per Person }{ }^{1}\left(\mathrm{~m}^{2}\right)\end{array}$ & $\begin{array}{c}\text { Window Area } \\
\left(\mathrm{m}^{2}\right)\end{array}$ & $\begin{array}{c}\text { Window } \\
\text { Area/Floor Area } \\
\text { Ratio }\end{array}$ \\
\hline $\mathrm{D}$ & 107 & 99 & 1.1 & 14.4 & 0.13 \\
\hline $\mathrm{E}$ & 125 & 100 & 1.3 & 28.8 & 0.23 \\
\hline $\mathrm{F}$ & 98 & 90 & 1.1 & 28.8 & 0.29 \\
\hline G & 95 & 80 & 1.2 & 14.4 & 0.15 \\
\hline $\mathrm{O}$ & 95 & 75 & 1.3 & 14.3 & 0.15 \\
\hline Cad & 112 & 39 & 2.9 & 14.4 & 0.13 \\
\hline $\mathrm{N}$ & 121 & 100 & 1.2 & 28.8 & 0.24 \\
\hline Infographic & 470 & 100 & 4.7 & 72.0 & 0.15 \\
\hline 21 & 60 & 56 & 1.1 & 12.0 & 0.20 \\
\hline 22 & 60 & 56 & 1.1 & 12.0 & 0.20 \\
\hline 23 & 60 & 56 & 1.1 & 12.0 & 0.20 \\
\hline 24 & 60 & 56 & 1.1 & 12.0 & 0.20 \\
\hline $\mathrm{T} 25$ & 120 & 90 & 1.3 & 19.2 & 0.16 \\
\hline Candia & 87 & 100 & 0.9 & 24.0 & 0.28 \\
\hline 107 & 65 & 24 & 2.7 & - & - \\
\hline 129 & 50 & 30 & 1.7 & 12.0 & 0.24 \\
\hline 119 & 62 & 35 & 1.8 & - & - \\
\hline 112 & 62 & 48 & 1.3 & - & - \\
\hline 106 & 45 & 40 & 1.1 & - & - \\
\hline EasyPC2 & 40 & 30 & 1.3 & 24.0 & 0.60 \\
\hline 126 & 110 & 96 & 1.1 & 24.0 & 0.22 \\
\hline 133 & 51 & 40 & 1.3 & 12.0 & 0.24 \\
\hline 136 & 51 & 40 & 1.3 & 12.0 & 0.24 \\
\hline T143 & 42 & 15 & 2.8 & 9.6 & 0.23 \\
\hline 137 & 110 & 32 & 3.4 & 24.0 & 0.22 \\
\hline Easy PC & 40 & 30 & 1.3 & 24.0 & 0.60 \\
\hline
\end{tabular}

${ }^{1}$ The usable surface per person is different for classrooms with a similar floor area due to the type of furniture (desks, seats). For example, for classrooms hosting PC, the index is higher.

The questionnaire was administered in May 2019 to 436 1st-year engineering students (on an overall number of 1,020 freshmen) and 126 students of subsequent years. They were all healthy volunteers selected among students usually attending the university spaces. Before the administration of the questionnaires, the subjects were informed about how the test will be carried out, giving all the necessary information, and avoiding any influence on their judgment. The interviewed are anonymous and the administration of the questionnaires was carried out during the breaks when students were calm and free to fill the questionnaires as long as it takes. Students of different years were involved to verify the possible effects of the year of enrolment, and thus, on the experience level of the place, and the subjective assessment of wayfinding (e.g., older students could orient at campus better than younger).

To make the subjective survey as truthful as possible, postprocessing of all the administrated questionnaires was carried out. Such a step was necessary as not each interviewee paid attention while filling the questionnaire. Therefore, when contradictory answers, the presence of too many erasures or multiple choices for the same question were found, the questionnaire was ignored.

In Figure 3 the investigated classrooms are represented by defining each floor as a level. In total 26 classrooms were investigated: 5 for level 1, 9 for level 2, and 12 for level 3. 

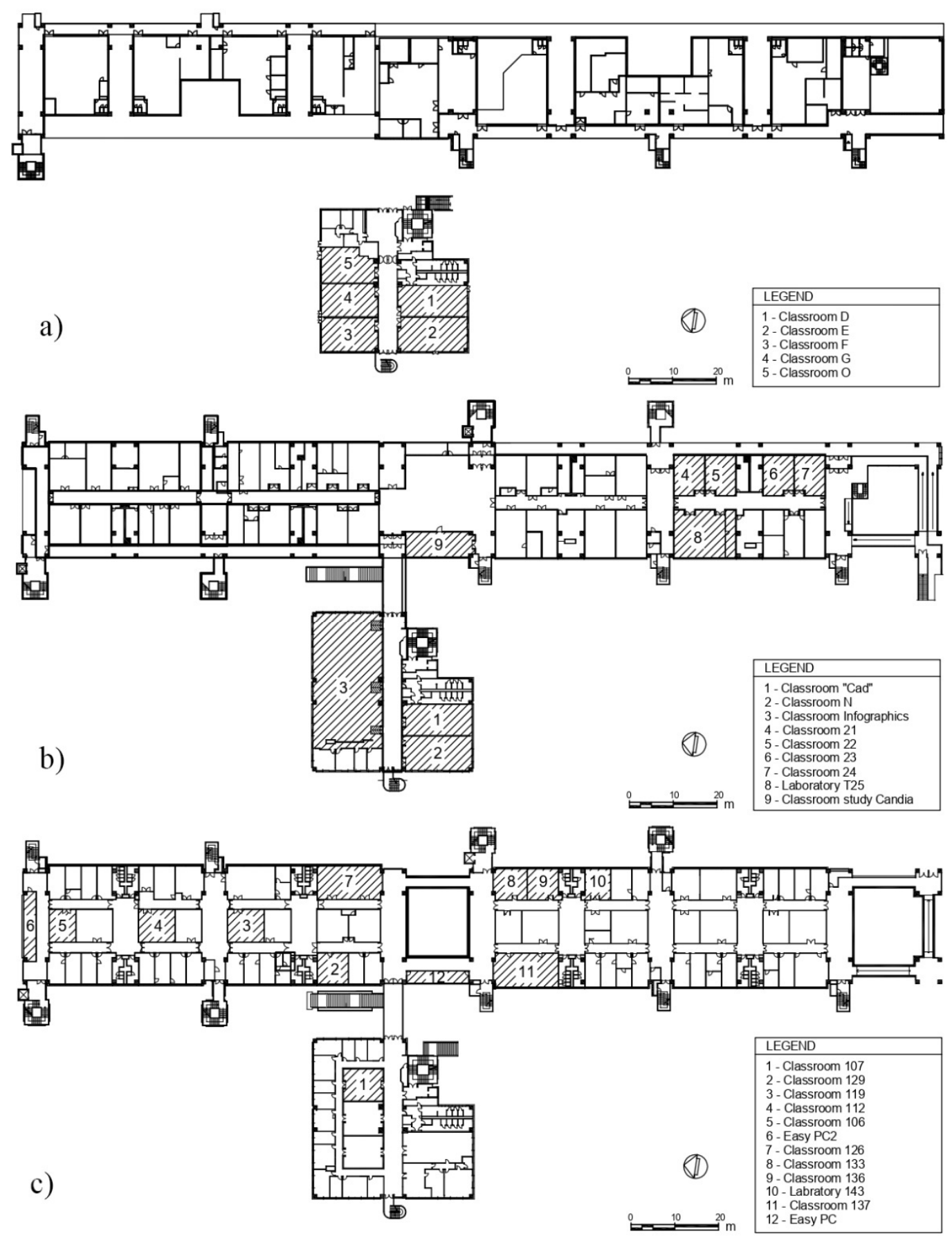

Figure 3. Investigated classrooms: (a) Level 1-basement of main building n. 5-6 and ground floor of secondary building $n$. 9c; (b) Level 2-ground floor of main building n. 5-6 and first floor of secondary building n. 9c; (c) Level 3-first floor of main building $n$. 5-6 and second floor of secondary building $n$. 9c.

The questionnaire consists of four parts, each containing a series of multiple answers with sections dedicated to open-ended questions (Appendix A).

The first part of the questionnaire contains general questions to gather the information that allows the understanding of the degree of knowledge of the students. It consists of two sections:

I. General data, containing questions about the user in terms of gender, age, degree program, and number of years of enrolment.

II. How the students utilize classrooms and spaces of the Faculty of Engineering. 
The first question is a filter question aimed at verifying whether students know and attend classrooms for lectures and study rooms. For this question, it was decided to make a distinction between 1st-year students and the others. This is to highlight possible differences between those who usually attend the university and those who do not do it.

\subsubsection{IEQ Subjective Assessment}

The second part of the questionnaire contains questions about IEQ and the perception of classrooms and spaces. This part of the questionnaire was designed according to ISO 10551 Standard. It is organized into four sections, each related to one of the aspects of IEQ. Table 2 summarizes the scales used for the subjective investigation.

Table 2. Scales used for evaluating the different aspects of IEQ [61].

\begin{tabular}{ccccc}
\hline Aspect & $\begin{array}{c}\text { Thermal } \\
\text { Comfort } \\
\text { (Perception) }\end{array}$ & $\begin{array}{c}\text { Indoor Air } \\
\text { Quality (IAQ) } \\
\text { (Evaluation) }\end{array}$ & $\begin{array}{c}\text { Visual Comfort } \\
\text { (Evaluation) }\end{array}$ & $\begin{array}{c}\text { Acoustic } \\
\text { Comfort } \\
\text { (Evaluation) }\end{array}$ \\
\hline \multirow{2}{*}{ Scale } & Very Cold & Very Satisfied & Very Satisfied & Very Satisfied \\
& Cold & Satisfied & Satisfied & Satisfied \\
& Indifferent & Indifferent & Indifferent & Indifferent \\
& Hot & Dissatisfied & Dissatisfied & Dissatisfied \\
& Very Hot & Very Dissatisfied & Very Dissatisfied & Very Dissatisfied \\
\hline
\end{tabular}

Regarding the scale for defining the thermal sensation, in the questionnaires we intentionally eliminated the points related to the sensations "extremely hot" and "extremely cold" because they are not applicable, and "slightly cold" and "slightly warm", which are sometimes problematic when interpretating to Italian.

\subsubsection{Subjective Assessment of the Perception of Interior Spaces}

This part of the questionnaire is based on the Guideline of the Cooperative Research Center for Construction Innovation in Brisbane (Australia) [62], which is aimed at defining basic principles, solutions, and strategies of signposting design. By applying design principles that account for how people relate to the physical world, some criteria for proper signposting and wayfinding design were identified, and classification was proposed according to the objectives as follows:

- Signposting of orientation: it helps the user to orient themselves and contains an indication (a list, map, or plan) of the functions hosted on the various floors of the building.

- Signposting of direction or sorting: guides the user along the route.

- Signposting of identification: indicates that the destination was reached.

- Signposting of information/education: includes communications, signals, and safety routes [63].

To assess how the internal space is perceived by the subjects, in the absence of reference standards, an original section of the questionnaire was created according to the different typology of users hanging out the Campus (see Appendix A). The questionnaire is structured aiming at investigating the degree of reception, ability on the orientation, shape of the buildings, and campus as a whole.

The questions were formulated on two evaluation scales:

- 4-point scale with extremes "definitely YES"-“definitely NO";

- 4-point scale with extremes "very"-"little".

Concerning aesthetics, there is also a 5-point scale with extremes "nice"-"ugly".

The questionnaire contains a further open-ended question about suggestions aimed at improving the livability of the spaces. 
Finally, there is a section of the questionnaire focused on the appearance and readability of the university spaces, which is based on specific questions on aesthetics and orientation issues.

\section{Results and Discussion}

Data processing was done by reporting the results by gender (Figure 4) for all the questions.

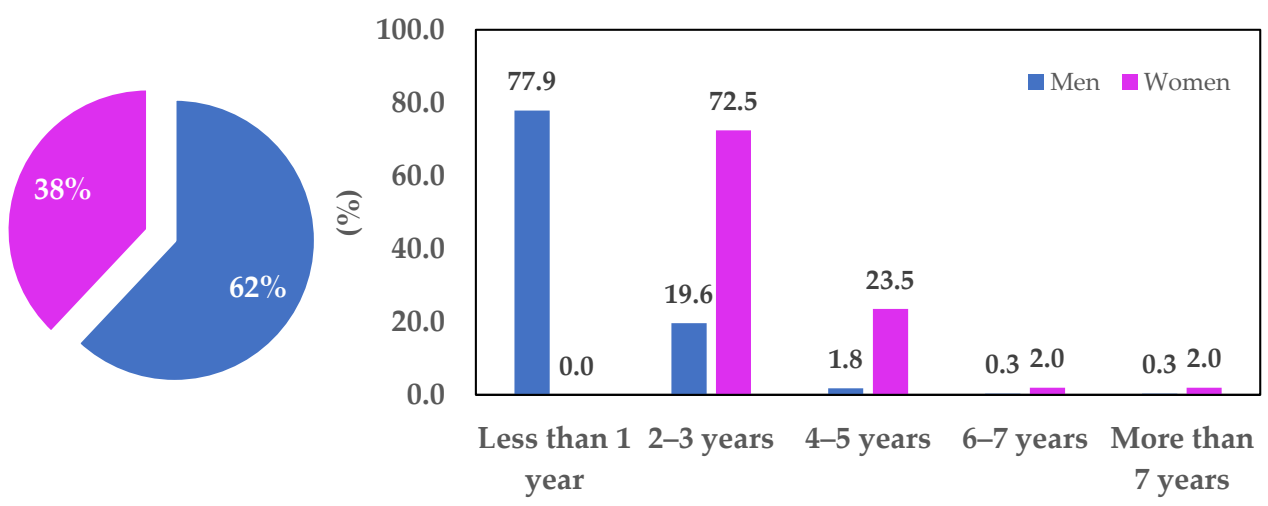

Figure 4. Distribution of respondents by gender (left) and enrolment (right).

\subsection{The Perception of the IEQ}

The results of subjective investigation for the 4 components of the IEQ are shown and discussed for both multiple-choice and open-ended questions. For each classroom, the judgment on each single facet of the IEQ was expressed by a percentage (multiple-choice questions) and complaints (open-ended questions). In the case of thermal comfort, due to the structure of the scale, the percentage of dissatisfied was calculated by assuming dissatisfied all people who did not vote "indifferent" on the perception scale (see Table 2). For IAQ, visual and thermal comfort, to simplify the reading and the interpretation of obtained results, the percentages of "Dissatisfied" and "Very dissatisfied" judgments were merged. This is because in most cases, the extreme judgments ("Very dissatisfied") were not relevant.

The limit value of the indifference judgment was evaluated to define if the classroom is adequate according to the following criteria:

- Indifferent judgment $<60 \%$ : inadequate classroom.

- Indifferent judgment $60-70 \%$ : adequate classroom.

- Indifferent judgment $>70 \%$ : quite adequate classroom.

IEQ judgment was negative for some classrooms, mainly due to IAQ and thermal comfort issues, as shown in Table 3, which reports the percentages of dissatisfied for each classroom. 


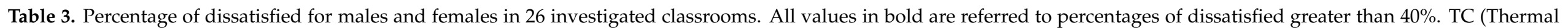
Comfort), IAQ (Indoor Air Quality), AC (Acoustic Comfort), VC (Visual comfort).

\begin{tabular}{|c|c|c|c|c|c|c|c|c|c|c|c|c|c|c|c|c|c|c|c|c|c|c|c|c|c|c|c|}
\hline \multirow{2}{*}{$\begin{array}{c}\text { IEQ } \\
\text { Component }\end{array}$} & \multirow[b]{2}{*}{ Gender } & \multicolumn{5}{|c|}{ Level 1} & \multicolumn{9}{|c|}{ Level 2} & \multicolumn{12}{|c|}{ Level 3} \\
\hline & & $\mathbf{D}$ & E & $\mathbf{F}$ & G & $\mathrm{O}$ & Cad & $\mathbf{N}$ & Infographic & 21 & 22 & 23 & 24 & T25 & Candia & 107 & 129 & 119 & 112 & 106 & $\begin{array}{l}\text { Easy } \\
\text { PC2 }\end{array}$ & 126 & 133 & 136 & T143 & 137 & $\begin{array}{c}\text { Easy } \\
\text { PC }\end{array}$ \\
\hline \multirow{2}{*}{$\mathrm{TC}$} & M & 36 & 39 & 38 & 37 & 38 & 18 & 43 & 28 & 26 & 29 & 27 & 26 & 33 & 54 & 33 & 23 & 23 & 22 & 24 & 42 & 30 & 26 & 23 & 33 & 22 & 37 \\
\hline & $\mathrm{F}$ & 34 & 32 & 39 & 37 & 36 & 27 & 41 & 36 & 29 & 29 & 32 & 30 & 29 & 73 & 36 & 38 & 33 & 35 & 38 & 31 & 45 & 23 & 23 & 19 & 21 & 30 \\
\hline \multirow{2}{*}{ IAQ } & $\mathrm{M}$ & 32 & 31 & 32 & 34 & 33 & 14 & 30 & 16 & 16 & 15 & 12 & 15 & 13 & 41 & 30 & 16 & 15 & 16 & 13 & 17 & 21 & 19 & 16 & 14 & 16 & 19 \\
\hline & $\mathrm{F}$ & 42 & 40 & 34 & 47 & 36 & 13 & 35 & 8 & 24 & 25 & 24 & 25 & 17 & 46 & 43 & 33 & 36 & 37 & 35 & 19 & 24 & 30 & 27 & 20 & 26 & 22 \\
\hline \multirow{2}{*}{$\mathrm{AC}$} & $\mathrm{M}$ & 26 & 26 & 26 & 29 & 27 & 10 & 27 & 14 & 20 & 20 & 25 & 21 & 7 & 37 & 26 & 21 & 22 & 21 & 21 & 33 & 24 & 20 & 19 & 8 & 18 & 32 \\
\hline & $\mathrm{F}$ & 20 & 25 & 21 & 21 & 22 & 6 & 22 & 17 & 21 & 20 & 22 & 21 & 4 & 30 & 21 & 18 & 16 & 16 & 18 & 11 & 20 & 6 & 12 & 4 & 7 & 14 \\
\hline \multirow{2}{*}{ VC } & $\mathrm{M}$ & 12 & 12 & 13 & 14 & 14 & 6 & 13 & 12 & 7 & 7 & 7 & 7 & 5 & 15 & 13 & 10 & 8 & 8 & 10 & 12 & 17 & 6 & 7 & 7 & 6 & 14 \\
\hline & $F$ & 23 & 22 & 18 & 24 & 24 & 9 & 21 & 14 & 16 & 15 & 14 & 18 & 11 & 20 & 23 & 26 & 28 & 28 & 27 & 11 & 28 & 6 & 10 & 6 & 5 & 9 \\
\hline
\end{tabular}


The complaints are reported only for classrooms where people answered open-ended questions, and they refer to different IEQ aspects, and differ for gender and classrooms as follows:

- In classrooms D, E, F, G, O, N, which are provided with counterposed ribbon windows allowing a good level of illumination (SW/SE exposure), students complained of stale air. Particularly, for the classroom N, some students believe that HVAC systems work poorly and complained of smoke during lessons. This is because classrooms are near the emergency stairs (outdoor) where students are used to smoke.

- In classrooms 21, 22, 23, and 24, which exhibit poor illumination due to the north exposure and the presence of an external porch, women are dissatisfied due to the poor ventilation and the noise from outside (these classrooms are located near very populated areas: e.g., bar, entrance halls, etc.).

- In T25 laboratory: 13\% of men claim hot conditions, identifying the poor ventilation as the reason for unacceptable comfort conditions.

- In Candia classroom, which is provided with a floor-to-ceiling window with south exposure, more than $50 \%$ of the whole sample of students was dissatisfied due to heat or cold conditions. Comfort conditions are not adequate due to improper air-conditioning and/or ventilation. In addition, the presence of glazed walls is responsible for discomfort conditions, especially in the summer season. Finally, women, compared to that of males, declared a greater dissatisfaction with respect to heat and cold conditions [60].

- In classroom 107, students complained of poor air exchange.

- In classroom 119, people complained about visual comfort. This is because the classroom is placed in the corridors where there are no windows and natural light is very poor.

- In the Easy PC and EASY PC 2 rooms, men complain about acoustic comfort. This is mainly related to the presence of glass walls lower than the net height of the building.

- In classroom 133, women complain of stale air.

\subsection{Preliminary Comparison with Thermal Comfort Objective Measurements}

To provide a first example about the relationship between the subjective survey (which is crucial to identify most critical conditions) and the objective analysis by measurements, in this section thermal comfort measurements carried out consistently with ISO 7730 [64] and ISO 7726 recommendations [65] are discussed. Concerning clothing thermal insulation and metabolic rate, reference values reported in ISO 7730 Standard [64] were considered (0.5 clo for the resultant clothing insulation, and $\mathrm{M}=1.3$ met for the metabolic rate, respectively [58]). The calculation of the PMV and PPD and local thermal discomfort indices was carried out by means of the TEE package [66]. Obtained PMV and PPD values and the main indicators of local thermal discomfort [64] are summarized in Table 4.

Data reported in Table 4 reveal lowest indoor environmental quality conditions in the four investigated classrooms. In addition, classroom 119 does not guarantee an adequate state of global thermal comfort (PMV < -0.7), with further local thermal discomfort caused by draughts. The comparison between subjective and objective investigation is shown in Table 5 where the distribution of persons who voted on the ASHRAE scale [67], and related PPD values obtained from the objective and subjective survey are shown. 


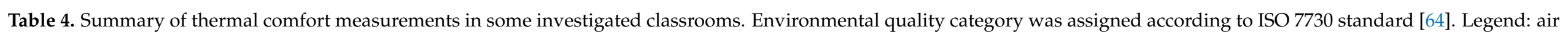

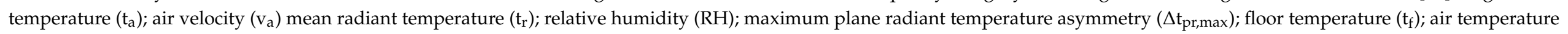
vertical gradient $\left(\Delta t_{a} / L\right)$; percentage of dissatisfied due to draught (DR).

\begin{tabular}{|c|c|c|c|c|c|c|c|c|c|c|c|c|c|}
\hline \multicolumn{6}{|c|}{ Measured Parameters } & \multicolumn{3}{|c|}{ Global Comfort } & \multicolumn{2}{|c|}{ Local Discomfort } & \multirow[b]{2}{*}{$\begin{array}{l}\text { DR } \\
(\%)\end{array}$} & \multicolumn{2}{|c|}{ Category } \\
\hline Classroom & Time & $\begin{array}{c}t_{a} \\
\left({ }^{\circ} \mathrm{C}\right)\end{array}$ & $\begin{array}{c}\mathrm{v}_{\mathrm{a}} \\
(\mathrm{m} / \mathrm{s})\end{array}$ & $\begin{array}{c}t_{r} \\
\left({ }^{\circ} \mathrm{C}\right)\end{array}$ & $\begin{array}{l}\text { RH } \\
\text { (\%) }\end{array}$ & $\begin{array}{c}\text { PMV } \\
(-)\end{array}$ & $\begin{array}{l}\text { PPD } \\
(\%)\end{array}$ & $\begin{array}{c}\Delta t_{\text {pr,max }} \\
\left({ }^{\circ} \mathrm{C}\right)\end{array}$ & $\begin{array}{c}t_{f} \\
\left({ }^{\circ} \mathrm{C}\right)\end{array}$ & $\begin{array}{c}\Delta \mathrm{t}_{\mathrm{a}} / \mathrm{L} \\
\left({ }^{\circ} \mathrm{C} / \mathrm{m}\right)\end{array}$ & & $\begin{array}{c}\text { Overall } \\
\text { Comfort }\end{array}$ & $\begin{array}{l}\text { Local Dis- } \\
\text { comfort }\end{array}$ \\
\hline $\mathrm{T} 25$ & $13: 50$ & 26.1 & 0.0002 & 26.5 & 60 & 0.62 & 13.1 & 0.5 & 26 & 0.2 & 0 & C & $\mathrm{A}$ \\
\hline Candia & $12: 50$ & 26.8 & 0.07 & 27.2 & 56 & 0.66 & 14.3 & -2 & 25.9 & -0.2 & 9.4 & $\mathrm{C}$ & A \\
\hline 119 & $15: 20$ & 22.2 & 0.16 & 24.4 & 56 & -0.72 & 15.9 & 1.1 & 24.2 & 0.7 & 22.6 & - & $\begin{array}{c}\mathrm{A}\left(\Delta \mathrm{t}_{\mathrm{pr}} ; \mathrm{t}_{\mathrm{f}}\right. \\
\left.\Delta \mathrm{t}_{\mathrm{a}} / \mathrm{L}\right)\end{array}$ \\
\hline 129 & $15: 40$ & 26.5 & 0.02 & 26.7 & 55 & 0.63 & 13.3 & 1.4 & 25.5 & 0.5 & 0 & C & $\mathrm{A}$ \\
\hline
\end{tabular}


Table 5. Comparison between objective measurement and subjective survey. Legend: percentage of dissatisfied by subjective investigation (PD); predicted percentage of dissatisfied by objective measurement (PPD); females (F); males (M).

\begin{tabular}{|c|c|c|c|c|c|c|c|c|c|c|c|}
\hline \multirow{3}{*}{ Classroom } & \multirow{3}{*}{$\begin{array}{c}\text { PPD } \\
(\%)\end{array}$} & \multicolumn{8}{|c|}{ Percentage of Dissatisfied Who Voted on the Evaluation Scale (\%) } & \multirow{2}{*}{\multicolumn{2}{|c|}{$\begin{array}{l}\text { PD } \\
(\%)\end{array}$}} \\
\hline & & \multicolumn{4}{|c|}{$\mathbf{M}$} & \multicolumn{4}{|c|}{$\mathbf{F}$} & & \\
\hline & & $\begin{array}{l}\text { Very } \\
\text { Cold }\end{array}$ & Cold & Hot & $\begin{array}{l}\text { Very } \\
\text { Hot }\end{array}$ & $\begin{array}{l}\text { Very } \\
\text { Cold }\end{array}$ & Cold & Hot & $\begin{array}{l}\text { Very } \\
\text { Hot }\end{array}$ & $\mathbf{M}$ & $\mathbf{F}$ \\
\hline $\mathrm{T} 25$ & 13.1 & 1.8 & 4.8 & 21.1 & 4.8 & 0.0 & 7.5 & 15.0 & 6.3 & 8.1 & 7.2 \\
\hline Candia & 14.3 & 4.5 & 20.2 & 19.1 & 10.1 & 9.5 & 21.9 & 24.8 & 17.1 & 13.5 & 18.3 \\
\hline 119 & 15.9 & 0.0 & 9.3 & 11.1 & 2.8 & 0.0 & 8.0 & 20.0 & 10.0 & 5.8 & 9.5 \\
\hline 129 & 13.3 & 0.0 & 10.1 & 10.1 & 3.0 & 0.0 & 7.1 & 19.0 & 7.1 & 5.8 & 8.3 \\
\hline
\end{tabular}

The comparison between PPD values and the percentages of dissatisfied obtained by the subjective evaluation (PD) reveals a certain agreement between subjective and objective measurements. Particularly, in T25 and Candia study classrooms, the average value of the dissatisfied (males) is closer to the value of the objective evaluation, whereas for classrooms 119 and 129, the percentage of dissatisfied (females) is closer to the PPD value obtained from the measurements. This partial agreement demonstrates that further investigations are required involving a specific analysis aimed at quantifying possible effects of real clothing insulation values and possible multisensory interactions between thermal comfort and other parameters affecting the IEQ (e.g., visual and acoustic comfort and IAQ) $[60,68]$.

\subsection{The Perception of the Interior Spaces}

The subjective survey was aimed at formulating an overview about the reception, orientation and overall quality of classrooms and connecting spaces. Data did not reveal meaningful percentage differences between students enrolled in the first year and those enrolled in subsequent years. Over $80 \%$ of students come to university both to attend the courses and to study, and among the study areas, the library is the most popular. Moreover, the following places are also mentioned as popular areas to study: free classrooms, small gardens/parks, former press center, language classrooms, model laboratory, Easy PC classroom, and reading rooms. The section of the questionnaire focused on the connectivity of spaces consists of questions about the orientation, aesthetics, and overall quality of these spaces (see Appendix A). The improvement interventions suggested in the open-ended questions by the students for these spaces were particularly significant.

The results of the subjective investigation about the adequacy of classroom and aesthetic of the spaces are shown in Figures 5 and 6.

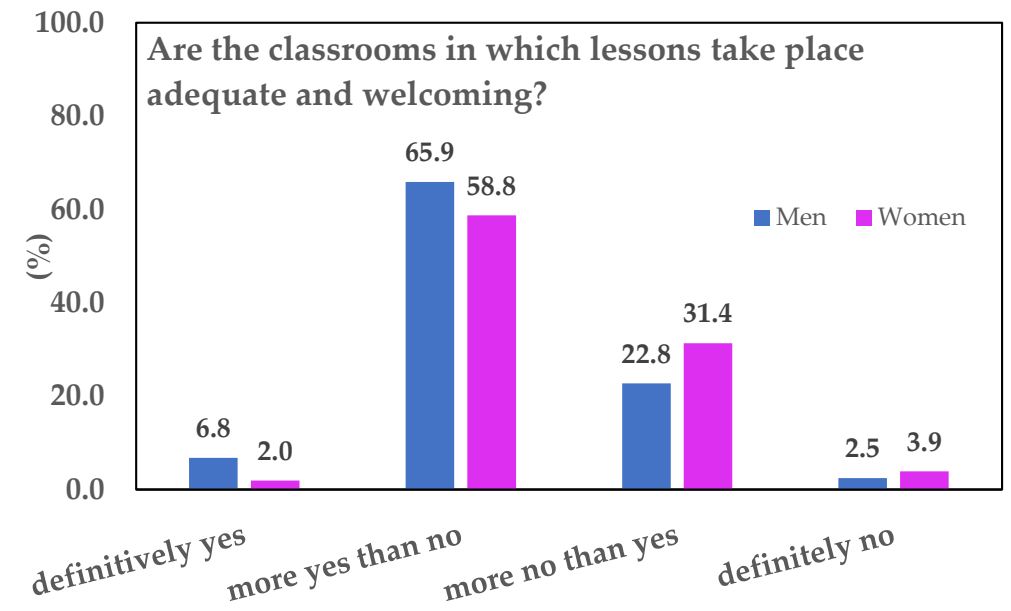

Figure 5. Adequacy and comfort of classrooms. 


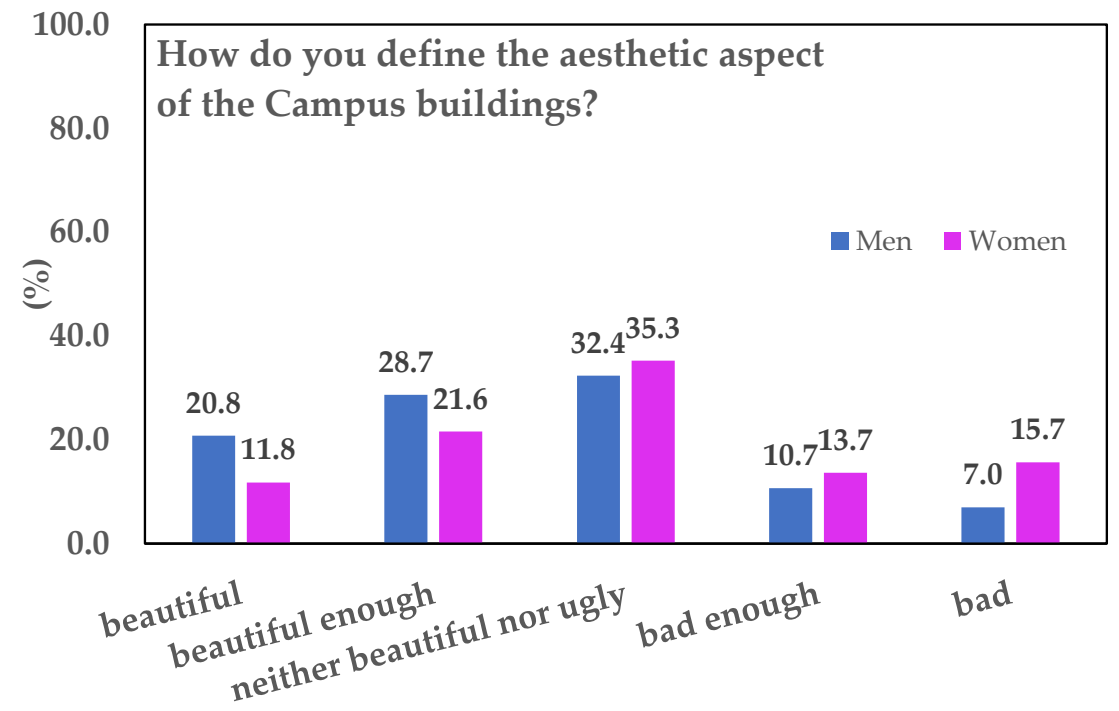

Figure 6. Aesthetic aspect of the Campus of Fisciano.

From the analysis of the distribution of votes given on the adequacy and comfort on indoor spaces (Figure 5) it seems that women were less satisfied than men (22.8\% instead of $31.4 \%$ ). This is not the case of the judgment on aesthetic issues (Figure 6) which seemed in good agreement (except for the extreme votes).

Both for students enrolled in the first year and for students enrolled in subsequent years, the most frequent problem that has emerged is the ability to orient themselves within the spaces of the campus. This similarity demonstrated how much is difficult to orient oneself within the campus even after years of attendance. Particularly, Figure 7 shows that over $50 \%$ of students $(\mathrm{F}=54.9 \%$; $\mathrm{M}=53.3 \%)$ declare a poor readability of the spaces.

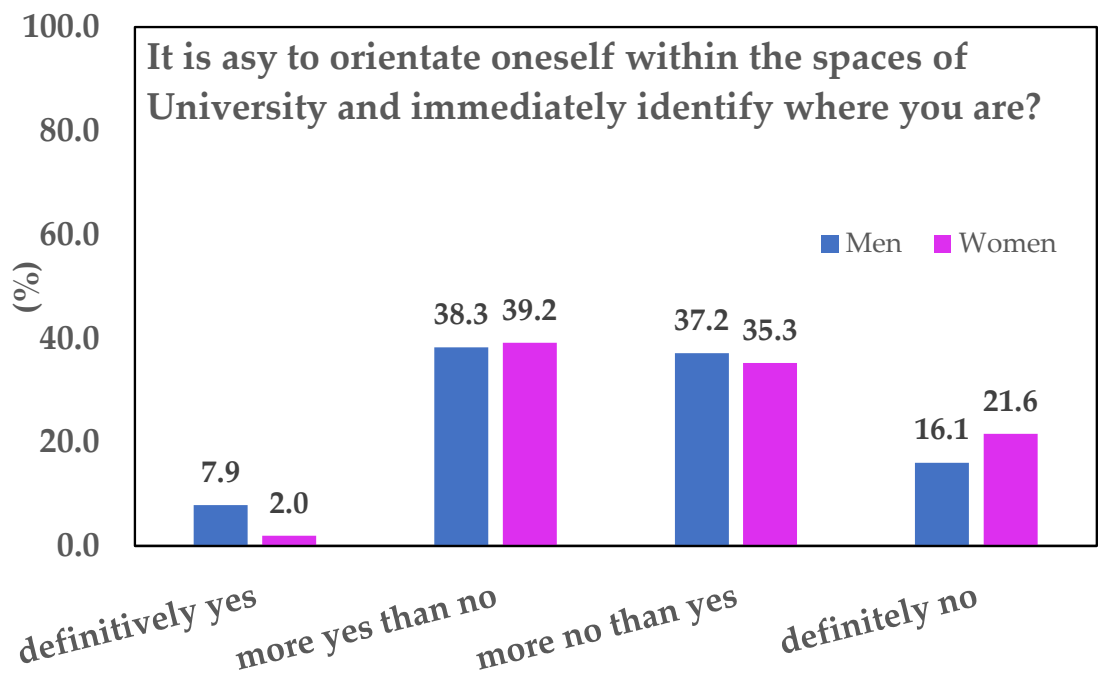

Figure 7. Readability of spaces on Campus of Fisciano.

Below are reported some indications proposed by the students, taken from the openended questions for the improvement of connective spaces:

- Orientation: indications for classrooms, laboratories, offices through the creation of maps and/or signposting placed at entrances or atriums and connective spaces and placement of PC/information point were suggested;

- Hospitality: installation of multiple seats and sockets, benches and tables, and flooring renewal aimed at modernizing rooms and making them cozier; 
- Overall quality: students suggest increasing the heterogeneity among the different environments, which appear too repetitive. To this purpose, they propose a diversification of the departments or the different areas through the use of thematic colors, adequate maintenance of these spaces, and better lighting.

\subsection{Proposals of Intervention}

\subsubsection{Façades}

The façades affect thermal and visual comfort (also acoustic in the classrooms without windows and equipped with skylight) and energy saving. They can be usefully involved in wayfinding.

For the façades we propose a double solution of sun-breakers with horizontal shielding for walls facing south — study classroom "Candia" —and with vertical shielding for walls exposed to the west. This last system was designed by Sauerbruch and Hutton, for the Mac567 building of the new Maciachini Center building [69] in Milan (Italy).

Vertical infills are made of double-skin walls provided with a ventilated cavity. On the outside, the silk-screened glass sheets are mounted on structures in metal profiles; inside, the closure is composed of sandwich insulating panels. All panels and shielding are of the same size (width: $0.50 \mathrm{~m}$, height: $2 \mathrm{~m}$ ) to facilitate assembly. The openable windows, with double-lowered double glazing, are provided with glass sheets (rotating up to $135^{\circ}$ ) which are automatically controlled as a function of the solar radiation. When the shielding systems are closed, the sunblind (Figure 8) defines coplanar surfaces, whereas, as the brise soleil is opened, the vertical scanning of the façades is emphasized.



Figure 8. Sunblind system applied to west-facing façade-main building 6 .

The colored closures have a variegated color spectrum that can be used to identify the external façades, and thus, facilitate orientation within the campus.

For the glass wall of the Candia study room, a photovoltaic solar shading system is proposed, which allows to regulate brightness and temperature inside the rooms.

\subsubsection{Classrooms without Windows}

For the classrooms not provided with windows whose skylights are not shielded and do not assure adequate levels of visual and acoustic comfort, we propose new skylights equipped with an electric opening system and incorporated shading devices with motors integrated inside the window frame and therefore invisible. The windows can be programmed and controlled by remote control with negligible effects on the energy demand, which is supported by $30 \%$ of renewable sources. 


\subsubsection{Signposting}

The proposed signposting offers a language that allows the user to orientate oneself and identify the places of interest to be reached. Primarily, focal points were identified (e.g., transition areas within different places where several paths converge). At these points, the Lynch's nodes theory was applied [70]. This procedure is usually applied to urban contexts but can be easily exported to the smaller scale of interior spaces of the campus, which are public spaces. In these points, a vertical signposting is proposed. It reports the indications of the places generally more sought after by those who attend the university. In the case of interest places, the signposting at the nodes indicates the classroom of the degrees, administrative offices, and secretariat and bar, as shown in Figure 9.

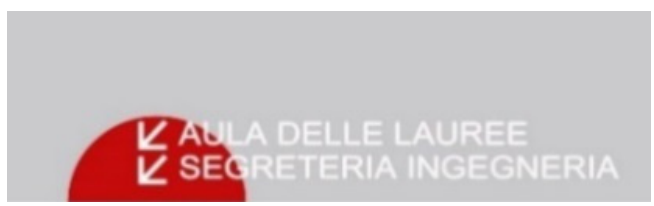

Figure 9. Signposting at nodes.

Secondary nodes were also identified. These spaces are placed close to the main nodes and allow quick identification of the different environments (classrooms, offices, and laboratories) when moving from one level to another. Figure 10 shows some examples of signposting.

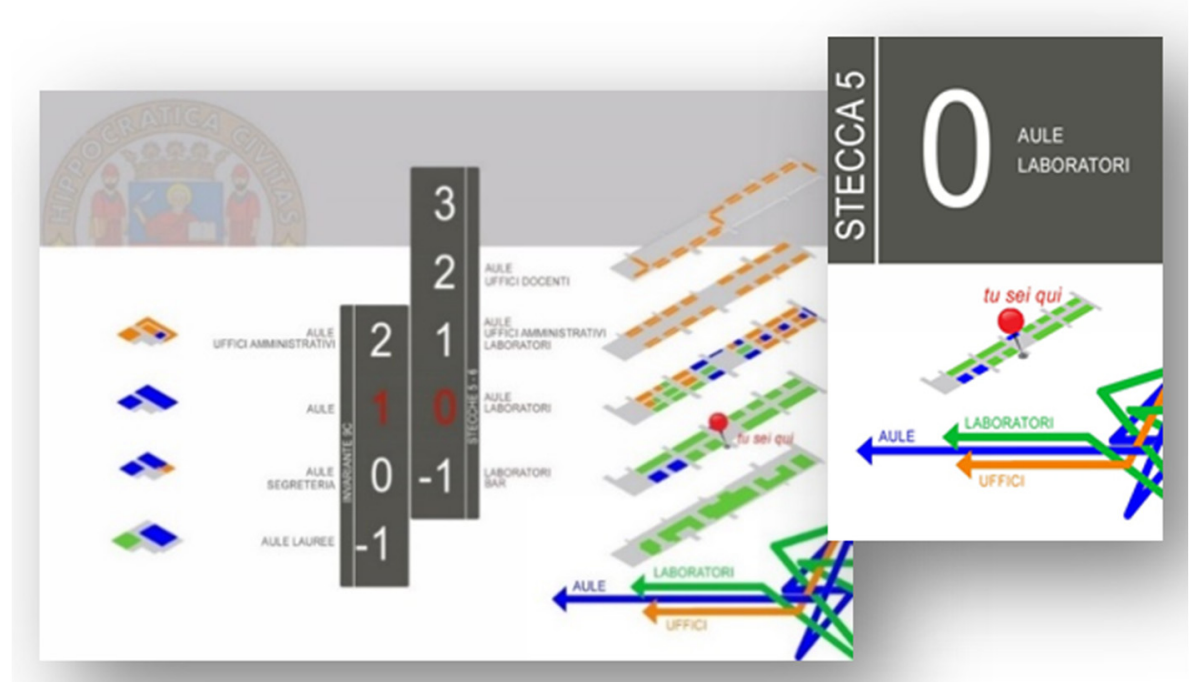

Figure 10. Signposting to secondary nodes: placed in correspondence of spaces accessible from outside and near lift.

Finally, a chromatic signposting is proposed to identify the paths related to classrooms, offices, and laboratories. In this way, through the chromatic component, it is possible to attract the attention of the observer and to favor his orientation.

The signposting proposed consists of a map located at the nodes, which shows (for each floor) the location of the rooms and their name. Figure 11 shows the route map. 


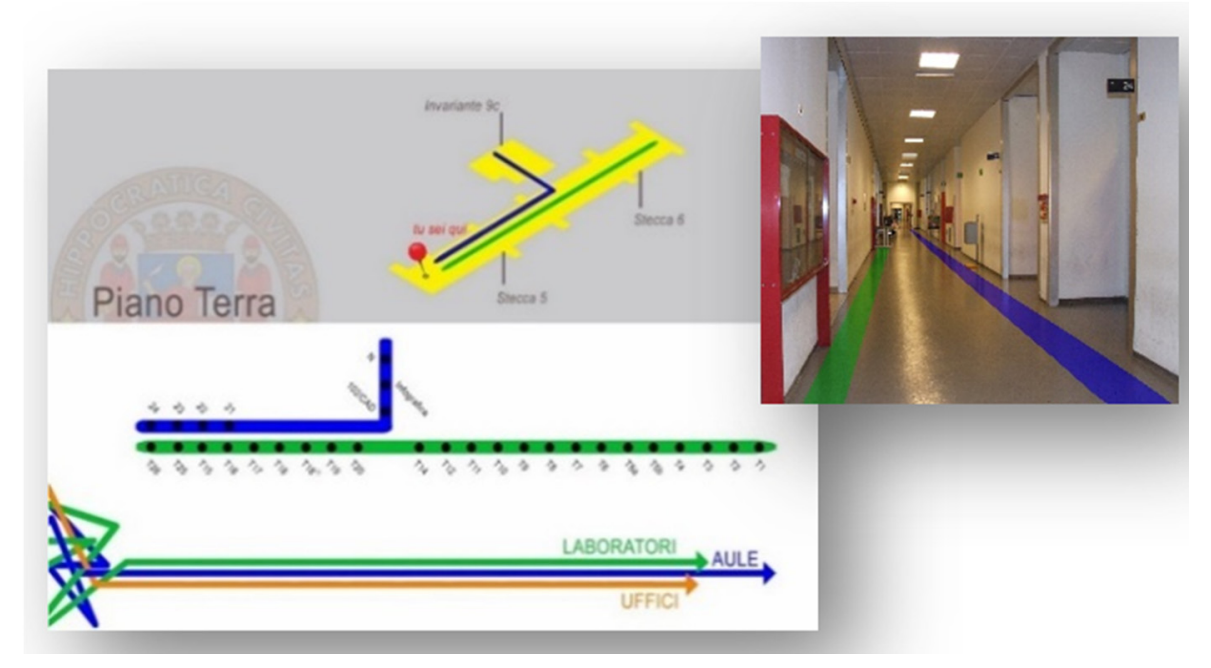

Figure 11. Map for locating rooms on plan.

\section{Conclusions}

The relationship between the quality of architectural spaces and the indoor environmental quality (IEQ) is a topic that acquired growing importance within the scientific community only recently. Unfortunately, these two aspects are usually treated separately, both in new and existing buildings with the risks of unbalanced solutions.

While the assessment of the IEQ can be carried out through consolidated subjective and objective investigations, some architectural features affecting orientation and wayfinding require subjective metrics. Therefore, the questionnaire is an indispensable tool that can contribute to giving information on the perceived built environment quality and orient any renovation project.

Due to the specificity of university campuses, which are complex organisms characterized by many activities, a series of actions aimed at facilitating and optimizing the activities of users is necessary to improve socialization by creating a sustainable living environment.

Based upon the premises as above, this paper proposed an integrated approach in the context of the sustainable redevelopment of complex realities such as university campuses. In particular, the paper combines the two aspects of the quality of the internal environments (e.g., thermal, visual, and acoustic comfort, and indoor air quality) with those concerning the quality of the interior spaces and those associated to energy efficiency in buildings.

The investigation, aimed at implementing a sustainable redevelopment of the Campus of the University of Salerno in Fisciano (Italy), gave particular attention to subjective evaluation, making the users of the campus the protagonists of an analysis for improving the daily fruition of indoor environments. In fact, the proposed interventions are the result of the problems emerging from the questionnaires and are aimed at simultaneously improving both aspects related to the quality of the rooms.

The methodology used in this survey could be the basis for a proposal applicable at the national level, through the Italian University Network for the Sustainable (RUS), as well as internationally.

Subjective data analysis returned interesting results that could be further investigated, especially in terms of gender-related or other issues' effects on experienced IEQ levels (e.g., age, social status, prolonged stay in the same place). Besides, the questionnaires could also be modified to aim at investigating other users who live in the campus spaces (e.g., teachers and administrative staff). The subjective investigation could also be integrated with objective measurements aimed at studying the correspondence with objective analyses and formulating an overall IEQ metric, which is still a debated topic.

While intervention strategies related to the orientation are easy to implement, those related to energy issues (e.g., installation of screens and photovoltaic systems) require careful energy analyses and technical-economic evaluations. Finally, as a final step of 
development aimed at a broader application to other buildings, the full integration of different skills is required (e.g., architects, engineers, psychologists). In this way, starting from users' needs, this method can provide designers with a more sustainable tool to qualify existing spaces.

Author Contributions: All authors contributed equally to the research: conceptualization, E.A., F.R.d.A., R.V., B.I.P. and D.P.; methodology, E.A., F.R.d.A., R.V., B.I.P. and D.P.; investigation, E.A., F.R.d.A., R.V., B.I.P. and D.P.; resources, E.A., F.R.d.A., R.V., B.I.P. and D.P.; writing—original draft preparation, review, and editing, E.A., F.R.d.A., R.V., B.I.P. and D.P. All authors have read and agreed to the published version of the manuscript.

Funding: This research was funded by University of Salerno, grant number ORSA171572.

Institutional Review Board Statement: Ethical review and approval were waived for this study because the investigation was anonymous on a voluntary basis, and no sensitive data were collected.

Informed Consent Statement: Informed consent was obtained from all subjects involved in the study.

Acknowledgments: The authors remember with esteem and affection Roberto Vanacore, who left us prematurely on 11 September 2020. We miss him.

Conflicts of Interest: The authors declare no conflict of interest. 


\section{Appendix A}

Questionnaire on the Spaces Perception in Unisa

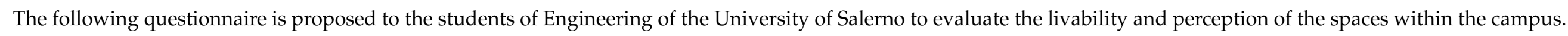

General Data

\section{Gender}

2. Age

under 20

\section{Degree course:}

Environmental and Land Planning Engineering

$\bigcirc \quad$ Food engineering

Digital health and bioinformatic Engineering
C Chemical Engineering

Electronic Engineering

- Civil and Environmental Engineering

\section{How many years have you been enrolled in university?}

○ 1 or less

○ $2-3$

- Building and Architectural Engineering

- Management Engineering
Electronic Engineering

○ Computer Engineering

Use and methods of use of the faculty

5. Why do you come to university?

just to attend the courses

Other reasons:

6. Do you use study spaces?

○ always 
7. What study spaces do you frequent?

study classroom "Candia"

library

Easy PC2 classroom

○ Other:

8. In general, are the classrooms in which the lessons take place adequate and welcoming?

$\bigcirc$ definitely yes

$\bigcirc$ more yes than no

more no than yes

definitely no

9. Specify the degree of satisfaction for the classrooms indicated in relation to the following parameters:






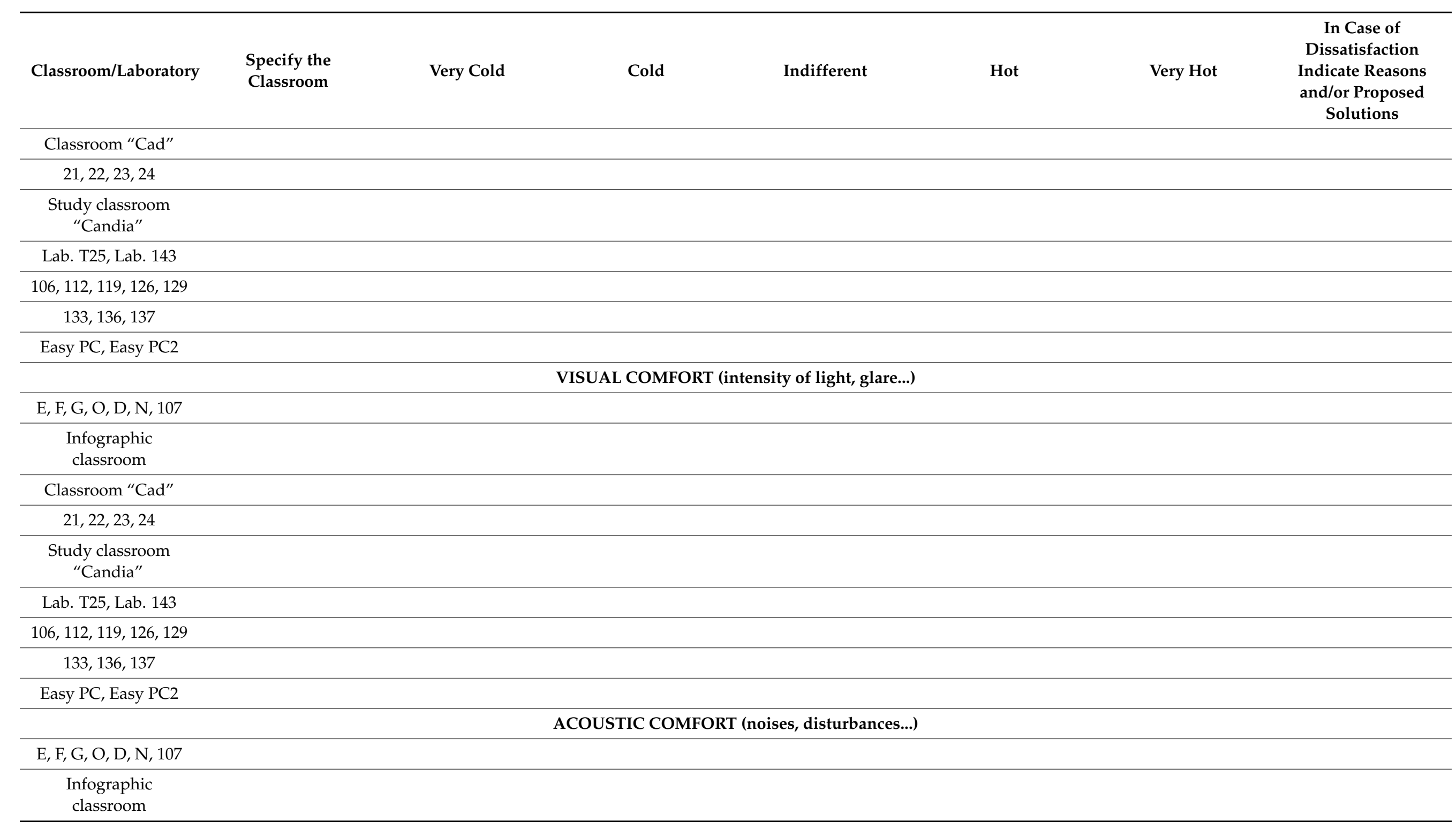




\begin{tabular}{|c|c|c|c|c|c|c|c|}
\hline Classroom/Laboratory & $\begin{array}{l}\text { Specify the } \\
\text { Classroom }\end{array}$ & Very Cold & Cold & Indifferent & Hot & Very Hot & $\begin{array}{c}\text { In Case of } \\
\text { Dissatisfaction } \\
\text { Indicate Reasons } \\
\text { and/or Proposed } \\
\text { Solutions }\end{array}$ \\
\hline \multicolumn{8}{|l|}{ Classroom "Cad" } \\
\hline \multicolumn{8}{|l|}{$21,22,23,24$} \\
\hline \multicolumn{8}{|l|}{$\begin{array}{l}\text { Study classroom } \\
\text { "Candia" }\end{array}$} \\
\hline \multicolumn{8}{|l|}{ Lab. T25, Lab. 143} \\
\hline \multicolumn{8}{|l|}{$106,112,119,126,129$} \\
\hline \multicolumn{8}{|l|}{$133,136,137$} \\
\hline Easy PC, Easy PC2 & & & & & & & \\
\hline
\end{tabular}

10. Specify the degree of satisfaction for connective spaces (atriums—for example CUES atrium-corridors, atriums near lifts and entrances):

- $\quad$ Do you define these welcoming spaces?

definitely yes more yes than no

more no than yes

definitely no

- Is it easy to orientate oneself within the spaces of University and immediately identify the place where you are?

definitely yes

more yes than no

more no than yes

definitely no

- How much is the overall quality of these spaces important for you (aesthetics, quality of the materials used for the flooring and wall coverings, effectiveness of the signposting, lighting)?
○ much
quite
not much
few

- Could you briefly list how the connective spaces could be improved? (max three staves)

Aesthetics and perception of university spaces

11. How do you define the aesthetic aspect of the spaces you normally attend to study (classrooms, connecting spaces-atriums, corridors)? 
beautiful

neither beautiful nor ugly

$\bigcirc \quad$ beautiful enough

bad enough

\section{How do you define the aesthetic aspect of the Campus buildings?}

$\bigcirc \quad$ beautiful

$\bigcirc \quad$ neither beautiful nor ugly

bad

beautiful enough

bad enough

13. How do orient yourself within the Campus?
very well
well

pretty well

not very well

not good at all 


\section{References}

1. Vijayavenkataraman, S.; Iniyan, S.; Goic, R. A review of climate change, mitigation and adaptation. Renew. Sustain. Energy Rev. 2012, 16, 878-897. [CrossRef]

2. Crawley, D.; Pless, S. Getting to net zero. ASHRAE J. 2009, 51, 18-25.

3. Kolokotsa, D.; Rovas, D.; Kosmatopoulos, E.; Kalaitzakis, K. A roadmap towards intelligent net zero- and positive-energy buildings. Sol. Energy 2001, 85, 3067-3084. [CrossRef]

4. Allard, F.; Braham, D.; van Dijk, D.; Feldmann, C.; Fox, J.; Gräslund, J.; Heiselberg, P.; Hovorka, F.; Kosonen, R.; Lebrun, J.; et al. REHVA nZEB Technical Definition and System Boundaries for Nearly Zero Energy Buildings; Kurnitski, J., Ed.; Federation of European Heating, Ventilation and Air Conditioning Associations: Brussels, Belgium, 2013; ISBN 9782930521091.

5. Becchio, C.; Bottero, M.C.; Corgnati, S.P.; Ghiglione, C. NZEB design: Challenging between energy and economic targets. Energy Procedia 2015, 78, 2070-2075. [CrossRef]

6. Chastas, P.; Theodosiou, T.; Bikas, D. Embodied energy in residential buildings-towards the nearly zero energy building: A literature review. Build. Environ. 2016, 105, 267-282. [CrossRef]

7. Zeiler, W.; Boxem, G. Net-zero energy building schools. Renew. Energy 2013, 49, 282-286. [CrossRef]

8. European Parliament. Directive (EU) 2018/844 of the European Parliament and of the Council of 30 May 2018 amending Directive 2010/31/EU on the energy performance of buildings and Directive 2012/27/EU on energy efficiency. Off. J. Eur. Union 2018, L 156, 75-91.

9. Browning, W.D.; Ryan, C.O.; Clancy, J.O. 14 Patterns of Biophilic Design; Terrapin Bright Green: New York, NY, USA, 2014; Available online: https:/ / www.terrapinbrightgreen.com/wp-content/uploads/2014/09/14-Patterns-of-Biophilic-Design-Terrapin-2014 p.pdf (accessed on 20 September 2021).

10. Kellert, S.R.; Heerwagen, J.; Mador, M. Biophilic Design: The Theory, Science and Practice of Bringing Buildings to Life; John Wiley \&Sons: Hoboken, NJ, USA, 2011; ISBN 978-0470163344.

11. Sayigh, A. Sustainability, Energy and Architecture (Case Studies in Realizing Green Buildings), 1st ed.; Academic Press: New York, NY, USA, 2014; p. 552. ISBN 9780123972699.

12. Guillén-Lambea, S.; Rodríguez-Soria, B.; Marín, J.M. Review of European ventilation strategies to meet the cooling and heating demands of nearly zero energy buildings (nZEB)/Passivhaus. Comparison with the USA. Renew. Sustain. Energy Rev. 2016, 62, 561-574. [CrossRef]

13. Medineckiene, M.; Zavadskas, E.K.; Björk, F.; Turskis, Z. Multi-criteria decision-making system for sustainable building assessment/certification. Arch. Civ. Mech. Eng. 2015, 15, 11-18. [CrossRef]

14. Attaianese, E. Green Buildings: The Role of HFE. In Ergonomics and Human Factors for a Sustainable Future; Thatcher, A., Yeow, P., Eds.; Palgrave-Macmillan: Singapore, 2018; pp. 211-242.

15. Attaianese, E. A broader consideration of human factor to enhance sustainable building design. Work 2012, 41 (Suppl. 1), 2155-2159. [CrossRef]

16. Thatcher, A.; Milner, K. Changes in productivity, psychological wellbeing and physical wellbeing from working in a 'green' building. Work 2014, 49, 381-393. [CrossRef] [PubMed]

17. Attaianese, E.; d'Ambrosio Alfano, F.R. The role of human factors/ergonomics for buildings energy sustainability. In Proceedings of the 51st International AiCARR Conference The Human Dimension of Building Energy Performance, Venice, Italy, 20-22 February 2019; pp. 11-24.

18. Attaianese, E. Environmental Design and Human Performance. In A Literature Review. In Proceedings of the 20th Congress of the International Ergonomics Association (IEA 2018), Florence, Italy, $26-30$ August 2018; Bagnara, S., Tartaglia, R., Albolino, S., Alexander, T., Fujita, Y., Eds.; Springer: Cham, Switzerland, 2019; pp. 486-495. [CrossRef]

19. Al Horr, Y.; Arif, M.; Kaushik, A.; Mazroei, A.; Katafygiotou, M.; Elsarrag, E. Occupant productivity and office indoor environment quality: A review of the literature. Build. Environ. 2016, 105, 369-389. [CrossRef]

20. Arias, A.; Leon, I.; Oregi, X.; Marieta, C. Environmental Assessment of University Campuses: The Case of the University of Navarra in Pamplona (Spain). Sustainability 2021, 13, 8588. [CrossRef]

21. Dober, P.R. Campus Landscape: Function, Forms, Features; John Wiley and Sons Inc.: New York, NY, USA, 2000; p. 288. ISBN 9780471353560.

22. Neuman, D.J. Building Type Basics for College and University Facilities, 2nd ed.; John Wiley \& Sons: New York, NY, USA, 2013; p. 415. ISBN 9781118008027.

23. Brooks, D.C. Space matters: The impact of formal learning environments on student learning. Br. J. Educ. Technol. 2011, 42, 719-726. [CrossRef]

24. Fassio, F.; Fanchiotti, A.; de Lieto Vollaro, R. Linear, Non-Linear and Alternative Algorithms in the Correlation of IEQ Factors with Global Comfort: A Case Study. Sustainability 2014, 6, 8113-8127. [CrossRef]

25. Zuhaiba, S.; Mantona, R.; Griffin, C.; Hajdukiewicza, M.; Keanea, M.M.; Goggins, J. An Indoor Environmental Quality (IEQ) assessment of a partially-retrofitted university building. Build. Environ. 2018, 139, 69-85. [CrossRef]

26. Akanmu, W.P.; Nunayon, S.S.; Eboson, U.C. Indoor environmental quality (IEQ) assessment of Nigerian university libraries: A pilot study. Energy Built Environ. 2021, 2, 302-314. [CrossRef]

27. National Institute of Building Sciences, Innovative Solutions for the Built Environment Washington, DC, USA. Available online: https: / / www.wbdg.org/design-objectives (accessed on 26 August 2021). 
28. Schexnayder, C.J.; Fiori, C.M. Handbook for Building Construction: Administration, Materials, Design, and Safety, 1st ed.; McGraw-Hill Education: New York, NY, USA, 2021; p. 608. ISBN 978-1260456882.

29. Koradecka, D. Handbook of Occupational Safety and Health. CRC Press: New York, NY, USA, 2010; p. 662. ISBN 9781439806845.

30. Bluyssen, P. The Indoor Environment Handbook: How to Make Buildings Healthy and Comfortable; Routledge: New York, NY, USA, 2015; p. 320. ISBN 9781844077878.

31. European Committee for Standardization. EN Standard 17210. In Accessibility and Usability of the Built Environment-Functional Requirements; European Committee for Standardization: Bruxelles, Belgium, 2021.

32. Piga, B.; Morello, E. Environmental design studies on perception and simulation: An urban design approach. Ambiances Environ. Sensib. Archit. Espace Urbain 2015, 1. [CrossRef]

33. Zhu, L.; Shan, M.; Hwang, B.-G. Overview of Design for Maintainability in Building and Construction Research. J. Perform. Constr. Facil. 2018, 32, 04017116. [CrossRef]

34. Loonen, R.C.G.M.; Trčka, M.; Cóstola, D.; Hensen, J.L.M. Climate adaptive building shells: State-of-the-art and future challenges. Renew. Sustain. Energy Rev. 2013, 25, 483-493. [CrossRef]

35. Zuo, J.; Zhao, Z.Y. Green building research-current status and future agenda: A review. Renew. Sustain. Energy Rev. 2014, 30, 271-281. [CrossRef]

36. Zagreus, L.; Huizenga, C.; Arens, E.; Lehrer, D. Listening to the occupants: A web-based indoor environmental quality survey. Indoor Air 2004, 114, 65-74. [CrossRef] [PubMed]

37. Sicignano, E. I Campus di Fisciano e Lancusi (1984-2011), Università degli Studi di Salerno; Gangemi Editore: Rome, Italy, 2011; p. 272, (In Italian). ISBN 9788849219302.

38. Dorizas, P.V.; Assimakopoulos, M.N.; Santamouris, M. A holistic approach for the assessment of the indoor environmental quality, student productivity, and energy consumption in primary schools. Environ. Monit Assess. 2015, 187, 259. [CrossRef] [PubMed]

39. Weisman, J. Evaluating Architectural Legibility: Way-Finding in the Built Environment. Environ. Behav 1981, 13, 189-204. [CrossRef]

40. Stiles, R. Methodology Plan for Good Planning and Designing of Urban Open Spaces. Available online: http:/ / urbanspace.rec. org/uploads/wp5-outputs-map/eng_methodology_plan_final.pdf (accessed on 15 July 2021).

41. Attaianese, E. Increasing sustainability by improving full use of public space: Human centered design for easy-to-walk built environment. Adv. Intel Syst Comp. 2016, 485, 473-483. [CrossRef]

42. Clemente, C. Périphériques. 16m Atrium, Paris. Available online: http://www.vg-hortus.it/index.php?option=com_content\& view=article\&id=167:pphques-16m-atrium\&catid=1:opere\&itemid=2 (accessed on 15 July 2021).

43. Lee, S.Y.; Brand, J.L. Effects of control over office workspace on perceptions of the work environment and work outcomes. J. Environ. Psychol. 2005, 25, 323-333. [CrossRef]

44. Veitch, J.A.; Newsham, G.R. Lighting quality and energy-efficiency effects on task performance, mood, health, satisfaction, and comfort. J. Illum. Eng. Soc. 1998, 27, 107-129. [CrossRef]

45. Steidle, A.; Werth, L. Freedom from constraints: Darkness and dim illumination promote creativity. J. Environ. Psychol. 2013, 35, 67-80. [CrossRef]

46. Kamarulzaman, N.; Saleh, A.A.; Hashim, S.Z.; Hashim, H.; Abdul-Ghani, A.A. An overview of the influence of physical office environments towards employees. Procedia Eng. 2011, 20, 262-268. [CrossRef]

47. Sakellaris, I.A.; Saraga, D.E.; Mandin, C.; Roda, C.; Fossati, S.; de Kluizenaar, Y.; Carrer, P.; Dimitroulopoulou, S.; Mihucz, V.G.; Szigeti, T.; et al. Perceived indoor environment and occupants' comfort in European "Modern" office buildings: The OFFICAIR Study. Int. J. Environ. Res. Public Health 2016, 13, 444. [CrossRef]

48. d'Ambrosio Alfano, F.R.; Olesen, B.W.; Palella, B.I. Povl Ole Fanger's impact ten years later. Energy Build. 2017, 152, 243-249. [CrossRef]

49. Fisk, W.J. Health and productivity gains from better indoor environments and their relationship with building energy efficiency. Annu. Rev. Energy Environ. 2000, 25, 537-566. [CrossRef]

50. Andersson, J.; Boerstra, A.; Clements-Croome, D.; Fitzner, K.; Hanssen, S.O. Indoor Climates and Productivity in Offices; Wargocki, P., Seppänen, O., Eds.; Federation of European Heating, Ventilation and Air Conditioning Associations: Brussels, Belgium, 2006; p. 78. ISBN 9782960046854.

51. Satish, U.; Mendell, M.J.; Shekhar, K.; Hotchi, T.; Sullivan, D.; Streufert, S.; Fisk, W.J. Is $\mathrm{CO}_{2}$ an indoor pollutant? Direct effects of low-to-moderate CO2 concentrations on human decision-making performance. Environ. Health Perspect. 2012, 120, 1671-1677. [CrossRef]

52. European Committee for Standardization. CEN EN Standard 16798-1. In Indoor Environmental Input Parameters for Design and Assessment of Energy Performance of Buildings Addressing Indoor Air Quality, Thermal Environment, Lighting and Acoustics-Module M1-6; European Committee for Standardization: Brussels, Belgium, 2019.

53. European Committee for Standardization. CEN EN Standard 16798-2. In Energy Performance of Buildings_Ventilation for BuildingsPart. 2: Interpretation of the Requirements in EN 16798-1-Indoor Environmental Input Parameters for Design and Assessment of Energy Performance of Buildings Addressing Indoor Air Quality, Thermal Environment, Lighting and Acoustics-Module M1-6; European Committee for Standardization: Brussels, Belgium, 2019.

54. American Society of Heating, Refrigerating and Air-Conditioning Engineer. ASHRAE Standard 202. In Commissioning Process for Buildings and Systems; American Society of Heating, Refrigerating and Air-Conditioning Engineers: Atlanta, GA, USA, 2018. 
55. ASHRAE Guideline 0. In The Commissioning Process; American Society of Heating, Refrigerating and Air-Conditioning Engineers: Atlanta, GA, USA, 2019.

56. Ente Italiano di Normazione. UNI Standard 10339. In Impianti Aeraulici ai Fini di Benessere. Generalità, Classificazione e Requisiti. Regole per la Richiesta d'Offerta, l'Offerta, l'Ordine e la Fornitura; (In Italian). Ente Italiano di Normazione: Milano, Italy, 1995.

57. Grivel, F.; Herrmann, C.; d'Ambrosio, F.R.; Candas, V. Thermal comfort analysis: Subjective data collection, methodology and reference conditions. Proceedings of 2nd International Conference Vehicle Comfort, Bologna, Italy, 14-16 October 1992; pp. 371-381.

58. d'Ambrosio Alfano, F.R.; Ianniello, E.; Palella, B.I. PMV-PPD and acceptability in naturally ventilated schools. Build. Environ. 2013, 67, 129-137. [CrossRef]

59. d'Ambrosio Alfano, F.R.; Dell'Isola, M.; Ficco, G.; Palella, B.I.; Riccio, G.; Frattolillo, A. Thermal Comfort in Supermarket's Refrigerated Areas: An Integrated Survey in Central Italy. Build. Environ. 2019, 166, 106410. [CrossRef]

60. d'Ambrosio Alfano, F.R.; Bellia, L.; Fragliasso, F.; Palella, B.I.; Riccio, G. On the interaction between lighting and thermal comfort: An integrated approach to IEQ. Energy Build. 2021, 231, 110570. [CrossRef]

61. International Standardization Organization. ISO Standard 10551. In Ergonomics of the Thermal Environment e Assessment of the Influence of the Thermal Environment Using Subjective Judgement Scales; International Standardization Organization: Geneva, Switzerland, 2019.

62. Apelt, R.; Crawford, J.; Hogan, D.J. Wayfinding Design Guidelines; Cooperative Research Centre for Construction Innovation: Brisbane, Australia, 2007; ISBN 9780980426298.

63. Indraganti, M.; Rao, K.D. Effect of age, gender, economic group and tenure on thermal comfort: A field study in residential buildings in hot and dry climate with seasonal variations. Energy Build. 2010, 42, 273-281. [CrossRef]

64. International Standardization Organization. ISO Standard 7730. In Ergonomics of the Thermal Environment-Analytical Determination and Interpretation of Thermal Comfort Using Calculation of the PMV and PPD Indices and Local Thermal Comfort; International Standardization Organization: Geneva, Switzerland, 2005.

65. International Standardization Organization. ISO Standard 7726. In Ergonomics of the Thermal Environment-Instruments for Measuring Physical Quantities; International Standardization Organization: Geneva, Switzerland, 1998.

66. d'Ambrosio Alfano, F.R.; Olesen, B.W.; Palella, B.I.; Pepe, D.; Riccio, G. Fifty years of PMV model: Reliability, implementation, and design of software for its calculation. Atmosphere 2020, 11, 49. [CrossRef]

67. American Society of Heating, Refrigerating, and Air-Conditioning Engineers, Inc. ASHRAE Standard 55. In Thermal Environmental Conditions for Human Occupancy; American Society of Heating, Refrigerating, and Air-Conditioning Engineers, Inc.: Atlanta, GA, USA, 2021.

68. Candas, V.; Dufour, A. Thermal comfort: Multisensory interactions? J. Physiol. Anthropol. 2005, 24, 33-36. [CrossRef]

69. Deka Immobilien Investment GmbH. Mac567. Available online: http:/ / www.mac567.com/it/ (accessed on 29 July 2021).

70. Lynch, K. The Image of the City; MIT Press: Cambridge, UK, 1960; p. 194. ISBN 0262120046. 